\title{
US shows good faith on help for developing countries
}

\begin{abstract}
Washington. One of the most vivid signs so far of the altered US stance on global environmental problems came last month, during the first session of the United Nations Commission on Sustainable Development.

The US delegation announced a partnership with Colombia on one of the most tangible goals outlined at the 1992 Rio conference: the exchange of environmental technology from developed to developing nations. In the coming year, officials from both countries will attempt to organize the transfer of technology for eco-efficient manufacturing, energy and transportation systems and sustainable agriculture and land use to developing countries.
\end{abstract}

At one level, the joint effort is symbolic, marking an about-face from former US President George Bush's obstructionist image at the Earth Summit. Colombia is the current head of the Group of 77, the coalition of 129 developing countries which has criticized the United States for environmental hypocrisy and for ignoring their right to develop as they see fit.

The partnership with Colombia is the latest in a series of moves by the Clinton mental politics worldwide. On 4 June, the United States signed the biodiversity treaty after having been alone among large counadministration to put its stamp on environ-

tries in refusing to do so. A month earlier, the US delegation pledged $\$ 100$ million to fund international population planning, reversing the 12-year policy of the Reagan and Bush administrations.

In April, President Clinton announced that the United States would go beyond the Bush policy on global warming by reducing emissions of greenhouse gases such as carbon dioxide to 1990 levels by 2000 .

Perhaps the most significant change in White House policy came with the acknowledgement that the US contribution to the degradation of the global environment has been disproportionately great. "Sometimes the developing countries are right...The affluent of the world have a responsibility to deal with their disproportionate impact," said US Vice-President Al Gore in his opening speech to the UN Commission.

Although some delegates from developing nations feel the United States is doing "too little, too late," many seemed encouraged by the new administration's change in policy. Tony Lambe, who coordinates the efforts of nongovernmental organizations' (NGOs) towards sustainable development for the body called Earth Council, says that while "it's still uncertain what Clinton will ultimately accomplish", the United States is "certainly making the right noises".

\section{Process patent bill on track}

Washington. A new law that would afford greater patent protection for US inventions in biotechnology and place the United States on a more equal footing with Europe and Japan inched one step closer to enactment last week, after receiving unanimous support in the US Senate.

As in past years, when the same bill was introduced but not enacted, Congress has to decide whether to tinker with US patent law and overturn a 1985 Federal Circuit Court ruling, In re Durden, which suggests that the use of a novel starting material in combination with a known chemical process is not eligible for process patent protection.

Supporters of the bill claim that over the past seven years, the US Patent and Trademark Office has erroneously and inconsistently used Durden either to delay or deny biotechnology process patents. This, they say, puts the United States at a considerable disadvantage in the face of competition from countries such as Europe and Japan, which routinely grant process patents.

Co-sponsored by Senator Dennis DeConcini (Democrat, Arizona) and Representative Rick Boucher (Democrat, Virginia), the Biotechnology Patent Protection
Act would not only amend existing US patent laws to include patent protection for genetically engineered processes when the combination of a novel starting material and a known process produces a useful product but would also close a legal loophole that allows foreign companies to export to the United States biotechnology products produced using components (such as host cells) patented in the United States.

Taken together, Boucher says that the bill would form "a comprehensive solution to the problem". But the passage of either of the parts independently would still be an effective solution, he says.

Although approved by the Senate, the bill's supporters are not yet in the clear as the proposal has yet to be voted on in the House of Representatives.

Past attempts to overrule Durden have been endorsed by the patent office but opposition remains among certain intellectual property groups on the grounds that the bill smacks of special interest legislation and amid concerns that it will lead to the automatic issuance of process patents which would increase uncertainty in the law.

Diane Gershon
The main accomplishments of the first meeting of the commission are thus intangible: US enthusiasm and reduced tensions between rich and poor countries, which exceeded expectations. Although no government formally committed funds to projects, developed countries agreed to encourage debt-relief for heavily indebted developing countries implementing environmental programmes. The commission also agreed that participants will submit annual reports on their progress towards Agenda 21, the action plan outlined at Rio. Environmentalists hope the reports will have the effect of encouraging compliance with Agenda 21, for which there are no formal enforcement procedures. Susan Greene

\section{European alarm on intellectual property}

Strasbourg. The European Parliament gave qualified assent last month to ratification by the European Communities (EC) of the UNCED (United Nations Conference on Environment and Development) convention on biodiversity, but expressed alarm over the EC's additional clause defending intellectual property rights. The accord, signed last year in Rio, is to be ratified by the $12 \mathrm{EC}$ member states and by the EC, in its own right, by the end of the year.

Some member states argue that the Treaty of Rome grants the EC no powers in the area of intellectual property rights. Parliament also deplored the move by the EC to follow the United States in drafting a unilateral 'interpretive declaration' which adds conditions to the agreement in Rio on sharing research benefits with developing countries.

But the commission insists that the biodiversity convention is partly concerned with trade in intellectual property - and it does have appropriate powers in the field of trade. While reaffirming EC support for the idea of technology and biotechnology transfer, the EC declaration insists that respect for intellectual property rights must be an "essential precondition". Transfers would entail "compliance with the principles and the rules of protection of intellectual property, and in particular multilateral and bilateral agreements signed or negotiated by the contracting parties to this convention".

This implies, complain parliamentarians, that patent rights are more important than the countries' sovereign rights over natural resources. Strasbourg urged that the declaration should be dropped, leaving NorthSouth negotiations on an equal footing. It can, however, do no more than urge. PreMaastricht, parliament has in fact little power to counter the combined weight of a common council and commission position. And EC commissioner Manuel Marin made it clear that he would not be shifted from his pro-council position, now likely to be ratified quite soon.

Arthur Rogers 